\title{
Dissolution of Plutonium Dioxide using $\mathrm{HCl}-\mathrm{HF}$
}

\author{
L. A. Bray \\ J. L. Ryan \\ E. J. Wheelwright
}

October 1986

Prepared for the U.S. Department of Energy under Contract DE-AC06-76RLO 1830

Pacific Northwest Laboratory

Operated for the U.S. Department of Energy by Battelle Memorial Institute 


\section{DISCLAIMER}

This report was prepared as an account of work sponsored by an agency of the United States Government. Neither the United States Government nor any agency Thereof, nor any of their employees, makes any warranty, express or implied, or assumes any legal liability or responsibility for the accuracy, completeness, or usefulness of any information, apparatus, product, or process disclosed, or represents that its use would not infringe privately owned rights. Reference herein to any specific commercial product, process, or service by trade name, trademark, manufacturer, or otherwise does not necessarily constitute or imply its endorsement, recommendation, or favoring by the United States Government or any agency thereof. The views and opinions of authors expressed herein do not necessarily state or reflect those of the United States Government or any agency thereof. 


\section{DISCLAIMER}

Portions of this document may be illegible in electronic image products. Images are produced from the best available original document. 

p

PNL- -6027

DE87 001870

\section{Dissolution of Plutonium \\ Dioxide using $\mathrm{HCl}-\mathrm{HF}$}

L. A. Bray

J. L. Ryan

E. J. Wheelwright

October 1986

Prepared for the U.S. Department of Energy under Contract DE-AC06-76RLO 1830

Pacific Northwest Laboratory Operated for the U.S. Department of Energy by Battelle Memorial Institute 
This report was prepared as an account of work sponsored by an agency of the United States Government. Neither the United States Government nor any agency thereof, nor any of their employees, makes any warranty, express or implied, or assumes any legal liability or responsibility for the accuracy, completeness, or usefulness of any information, apparatus, product, or process disclosed, or represents that its use would not infringe privately owned rights. Reference herein to any specific commercial product, process, or service by trade name, trademark, manufacturer, or otherwise does not necessarily constitute or imply its endorsement, recommendation, or favoring by the United States Government or any agency thereof. The views and opinions of authors expressed herein do not necessarily state or reflect those of the United States Government or any agency thereof.

\section{DISSOLUTION OF PLUTONIUM DIOXIDE} USING $H C l-H F$

L. A. Bray

J. L. Ryan

E. J. Wheelwright

October 1986

Prepared for

the U.S. Department of Energy

under Contract DE-AC06-76RLO 1830

Pacific Northwest Laboratory

Richland, Washington 99352 
$$
\text { . }
$$ 
High-fired $\mathrm{PuO}_{2}\left(950^{\circ}\right.$ to $\left.1700^{\circ} \mathrm{C}\right)$ can be dissolved in boiling $6.1 \mathrm{M} \mathrm{HCl}$ when the fluoride ion concentration to plutonium mole $\left(\mathrm{F}^{-} / \mathrm{Pu}\right)$ ratio is $>0.5$. The amount of $\mathrm{PuO}_{2}\left(950^{\circ} \mathrm{C}\right.$ calcined oxide) dissolved in 1 hour increased from $\sim 0.2 \%$ to $66 \%, 91 \%$, and $100 \%$ as the $\mathrm{F}^{-} / \mathrm{Pu}$ ratio increased from 0 to $0.5,1.0$, and 1.8 , respectively. The $\mathrm{PuO}_{2}$ dissolution rates in $\mathrm{HCl}-\mathrm{CaF}_{2}$ solutions decrease with increasing oxide calcination temperatures and decreasing oxide surface areas. At a $\mathrm{F}^{-} / \mathrm{Pu}$ ratio of 1.8 , the $1700^{\circ} \mathrm{C}$ calcined oxide was completely dissolved in 2.5 hours versus 1 hour for the $950^{\circ} \mathrm{C}$ calcined oxide. 
$$
\text { . }
$$ 


\section{CONTENTS}

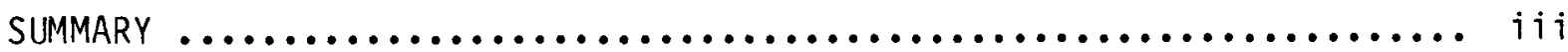

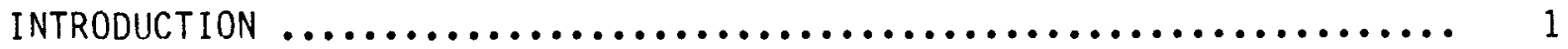

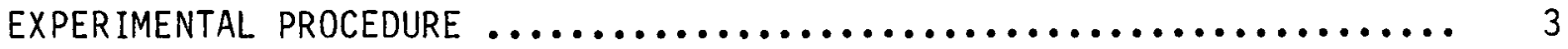

PREPARATION OF PLUTONIUM DIOXIDE $\ldots \ldots \ldots \ldots \ldots \ldots \ldots \ldots \ldots \ldots \ldots \ldots$

DISSOLIJTION TESTS USING HCl OR $\mathrm{HCl}-\mathrm{CaF}_{2} \ldots \ldots \ldots \ldots \ldots \ldots \ldots \ldots \ldots \ldots$

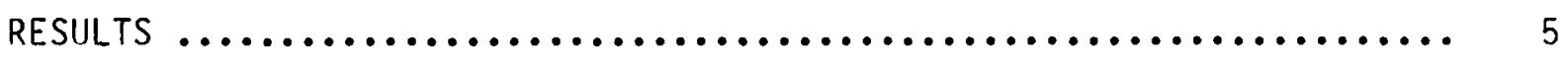

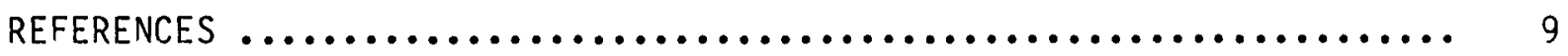

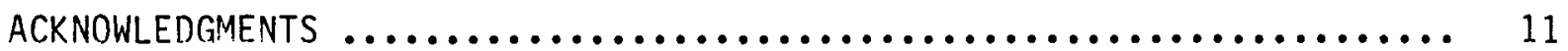


At the request of Rockwe11 Hanford Operations, Pacific Northwest Laboratory (PNL) has completed a preliminary study to determine 1) if plutonium dioxide $\left(\mathrm{PuO}_{2}\right)$ can be satisfactorily and completely dissolved in constant boiling (6.1 M) hydrochloric acid ( $\mathrm{HCl})$, and (2) the dissolution rates for oxides of known surface area. A method for dissolution of $\mathrm{PuO}_{2}$ in $\mathrm{HCl}$ is desired in order to dissolve scrap $\mathrm{PuO}_{2}$ in a plutonium recovery process designed principally to support pyrochemical processing of chloride salts. This recovery process is based on chloride anion exchange of the plutonium.

Several methods have been studied for the dissolution of $\mathrm{PuC}_{2}$. The most common method was the use of nitric acid containing a small concentration of fluoride usually added as HF. Cleveland (1970), Ryan and Bray (1980) have reviewed dissolution methods up to about 1980. Aqueous methods, other than $\mathrm{HNO}_{3}-\mathrm{HF}$, included the use of acids such as $\mathrm{HI}, \mathrm{HBr}$, and $\mathrm{HCl}$ containing $\mathrm{SnCl}_{2}$ (Cleveland 1964; Molen 1967). Refractory $\mathrm{PuO}_{2}$ dissolves extremely slowly in mineral acids; rates decrease as the calcination temperature of the oxide increases (Bjorklund and Staritzky 1954; Baehr and Dippel 1967). No dissolution data are known for mixtures of $\mathrm{HCl}-\mathrm{HF}$. 
$$
\text { . }
$$ 
This section details the preparation of plutonium dioxide, the dissolution procedure, and the equipment used in these tests.

PREPARATION OF PLUTONIUM DIOXIDE

Plutonium dioxide intended for use in the dissolution tests was specially prepared and characterized. Plutonium solutions from nitric acid-anion exchange purification were adjusted to $0.05 \mathrm{M}$ in hydrazine to destroy nitrite ions; ascorbic acid was added to reduce the plutonium to plutonium (III); and oxalic acid was added to precipitate plutonium (III) oxalate. The filtered oxalate was dried and divided into three batches that were calcined for 2 hours in air in alumina crucibles at $350^{\circ} \mathrm{C}, 500^{\circ} \mathrm{C}$, or $950^{\circ} \mathrm{C}$. Part of the $950^{\circ} \mathrm{C}$ batch was recalcined in a zirconia crucible at $1700^{\circ} \mathrm{C}$ in water-saturated $92 \% \mathrm{Ar}-8 \% \mathrm{H}_{2}$ to provide highly sintered oxide. The $350^{\circ} \mathrm{C}$ calcined oxide had a surface area of $48.7 \mathrm{~m}^{2} / \mathrm{g}$; the $500^{\circ} \mathrm{C}$ oxide, $39.4 \mathrm{~m}^{2} / \mathrm{g}$; the $950^{\circ} \mathrm{C}$ oxide, $1.5 \mathrm{~m}^{2} / \mathrm{g}$; and the $1700^{\circ} \mathrm{C}$ oxide, $0.54 \mathrm{~m}^{2} / \mathrm{g}$, as determined by a modified BET method. The importance of this difference in the surface areas of the four oxide batches is evident from the dissolution tests.

DISSOLUTION TESTS USING HCl OR HCI-CaF 2

Samples of each of the four batches of oxide were dissolved in constant boiling $\mathrm{HCl}(6.1 \mathrm{M})$ or $\mathrm{HCl}$ containing known amounts of $\mathrm{CaF}_{2}$. The tests were conducted in a standard narrow mouth (\$24/40 joint) Erlenmeyer flask. The flask was fitted with a condenser with a $\$ 24 / 40$ inner joint at the bottom. Condenser water was cooled to $6^{\circ} \mathrm{C}$ with a temperature bath. The dissolver was heated on a stirring hot plate, and the solution was mixed by a Teflon ${ }^{\circledR}$-coated magnetic bar. The solution was heated to intended dissolution temperature, then a measured amount of oxide was added to avoid a heatup cycle. Samples were withdrawn and filtered at appointed time intervals, and plutoni um content in the aqueous phase was determined.

(2) Tefion is a trademark of E. I. du Pont de Nemours. 
$$
\text { . }
$$ 
RESULTS

Rates of dissolution for the various experimental conditions used in this study are shown in Figure 1 . In the absence of fluoride, high-fired $\mathrm{PuO}_{2}$ $\left(>950^{\circ} \mathrm{C}\right)$ was practically insoluble in boiling $(6.1 \mathrm{M}) \mathrm{HCl}$, and lower-fired oxide dissolved very slowly. The dissolution rates in pure $\mathrm{HCl}$ decrease markedly with increasing calcination temperature of the oxide. The amount of oxide dissolved in 5 hours was $28 \%, 7 \%$, and $\sim 0.2 \%$ for $350^{\circ} \mathrm{C}, 500^{\circ} \mathrm{C}$, and $950^{\circ} \mathrm{C}$ calcined oxide, respectively (the same order as the measured $\mathrm{PuO}_{2}$ surface areas). An exact correlation with surface area was not observed or expected since $350^{\circ} \mathrm{C}$ calcined $\mathrm{Pu}$ (III) oxalate is probably not completely converted to $\mathrm{PuO}_{2}$ (Cleveland 1970). In addition, all surface areas measured by the BET gas absorption method may not be readily available for aqueous dissolution. The results at $950^{\circ} \mathrm{C}$ are similar to those found by Cleveland (1964). Cleveland found that only $0.74 \%$ of the initial $\mathrm{PuO}_{2}$ dissolved after 1 hour. The $\mathrm{PuO}_{2}$ had been prepared by burning metal in air, and $10 \mathrm{~g}$ of the oxide had been treated with $100 \mathrm{~mL}$ of boiling $12 \mathrm{M} \mathrm{HCl}$.

With fluoride added to the dissolvent, the rate of $\mathrm{PuO}_{2}$ dissolution increased significantly as the fluoride to plutonium mole ( $F^{-} / \mathrm{Pu}$ ) ratio increased from 0 to 2. For $950^{\circ} \mathrm{C}$ calcined oxide, the amount of $\mathrm{PuO}_{2}$ dissolved in the first hour increased from $\sim 0.2 \%$ to $66 \%, 91 \%$, and $100 \%$ as the $\mathrm{F}^{-} / \mathrm{Pu}$ ratio increased from 0 to $0.5,1.0$, and 1.8 , respectively. As shown in Figure 1, the dissolution rate in $\mathrm{HCl}-\mathrm{CaF}_{2}$ solutions decreases with an increase in oxide calcination temperature and a corresponding decrease in oxide surface area. At a $\mathrm{F}^{-} / \mathrm{Pu}$ ratio of 1.0 , only $35 \%$ of the $1700^{\circ} \mathrm{C}$ calcined oxide dissolved in 1 hour versus $91 \%$ for the $950^{\circ} \mathrm{C}$ calcined oxide. At a $\mathrm{F}^{-} / \mathrm{Pu}$ ratio of 1.8 , complete dissolution of the $1700^{\circ} \mathrm{C}$ calcined oxide required 2.5 hours versus 1 hour for the $950^{\circ} \mathrm{C}$ calcined oxide. Acceptable dissolution rates for $\mathrm{PuO}_{2}$ can be obtained in $\mathrm{HCl}$ solutions containing $\mathrm{F}^{-}$in a ratio to $\mathrm{Pu}$ of about 2. Fluoride interferes with $\mathrm{HCl} \mathrm{Pu}(\mathrm{IV})$ anion exchange, but the addition of $\mathrm{Al}^{3+}$ ion after dissolution to complex the $\mathrm{F}^{-}$ion will counteract this effect.

No studies were performed to determine the effect of other metallic impurities on the dissolution rate of $\mathrm{PuO}_{2}$ in $\mathrm{HCl}-\mathrm{CaF}_{2}$ solutions. 


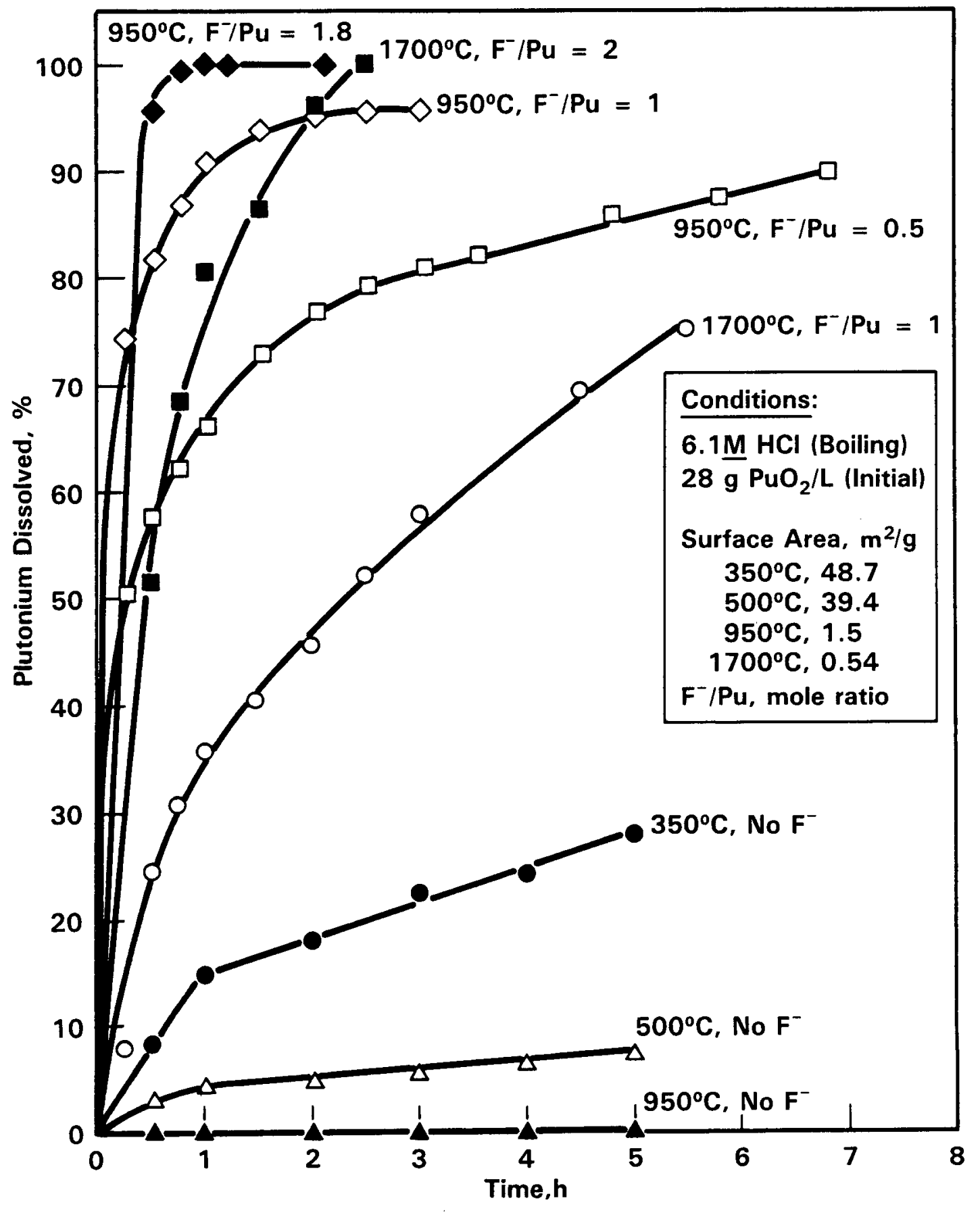

FIGURE 1. Dissolution of $\mathrm{PuO}_{2}$ Using $\mathrm{HCl}$ and $\mathrm{CaF}_{2}$ 


\begin{abstract}
,
Metallic impurities which complex fluoride strongly may be present in quantities approaching total fluoride concentration. Extrapolation from the nitric acid-fluoride system indicates that these impurities will markedly influence $\mathrm{PuO}_{2}$ dissolution by lowering free $\mathrm{F}^{-}$and $\mathrm{HF}$ activities (Ryan and Bray 1980). Assuming that at any given acidity the $\mathrm{PuO}_{2}$ dissolution rate is first order with respect to free (uncomplexed to meta 1) fluoride or HF concentration, the effects of various fluoride complexing metal ions at $25^{\circ} \mathrm{C}$ can be estimated from their complex formation constants (Sillen and Martel) 1964).
\end{abstract}


$$
\text { . }
$$ 
Baehr, W., and T. Dippel. 1967. On the Dissolution of Breeder Fuels Containing $\mathrm{PuO}_{2}$ in Nitric Acid for Aqueous Reprocessing by the PUREX Method. KFK-6/3 (EURFNR-4TI), European Atom Company, Atomic Research Co., Ltd., Karlsruhe, G. E.

Bjorklund, C. W., and E. Staritzky. 1954. Some Observations of the Reactivity of $\mathrm{PuO}_{2}$. LA-1869, Los Alamos, New Mexico.

Cleveland, J. M. 1964. "Dissolution of Refractory Plutonium Dioxide." J. Inorg. Nuc 1. Chem. 26:1471-1472.

Cleveland, J. M. 1970. The Chemistry of Plutonium. Gordon and Breach, New York, pp. 398-407 and 574-575.

Molen, G. F. 1967. Dissolution of Plutonium Dioxide. RPF-922, Dow Chemical Company, Golden, CoTorado.

Ryan, J. L., and L. A. Bray. 1980. "Dissolution of Plutonium Dioxide - A Critical Review." ACS Symposium Series 117:499.

Sillen, L. G., and A. E. Marte11. 1964. "Stability Constants of Metal-Ion Complexes." The Chemical Society, pp. 259-261, London. 
$$
\text { . }
$$ 


\section{ACKNOWLEDGMENTS}

The authors wish to thank T. R. Myers for assistance in the laboratory, and E. H. Shade for preparation of the $1700^{\circ} \mathrm{C}$ calcined oxide. 


\section{DISTRIBUTION}

No. of

Copies

OFFSITE

30 DOE Technical Information Center

B. R. Myers

Lawrence Livermore National Laboratory

P.0. Box 808

Livermore, CA 94550

\section{ONSITE}

5 DOE Richland Operations Office
G. M. Chenevert
J. K. Sherrodd
D. P. Simonson
J. J. Sutey
M. J. Zamorski

No. of

Copies

3 Rockwell Hanford Operations

F. D. Fisher

0. L. Kruger

R. K. Welty

47 Pacific Northwest Laboratory

L. A. Bray (10)

L. L. Burger

D. G. Coles

P. E. Hart

R. S. Kemper

J. L. MCElroy

T. R. Myers

J. L. Ryan (10)

J. A. Shaw

J. L. Straalsund

J. W. Wald

P. C. Walkup

E. J. Wheelwright (10)

Publishing Coordination (2)

Technical Information (5) 